\title{
Seed protein analyses as a support to the transfer of Trigonella cylindracea Desv. and T. polyceratia $(\mathrm{L}$. Trautv. to genus Medicago L.
}

\author{
Ream I. Marzouk
}

Botany Dept., Faculty of Science, Alexandria University, Alexandria, Egypt. e-mail: reammarzouk@yahoo.com

Marzouk R.I. 2006. Seed protein analyses as a support to the transfer of Trigonella cylindracea Desv. and T. polyceratia (L.) Trautv. to genus Medicago L. Taeckholmia 26: 17-33.

\footnotetext{
The present study has been planned to investigate the extent to which seed proteins and peptide mapping may be used as evidences to discuss the position of T. cylindracea Desv. and T. Polyceratia (L.) Trautv. To achieve this objective two outgroups (reference species): Trigonella foenum-graecum L. and Medicago sativa L., represent the type species for each genus were used. Each species was considered as an operational taxonomic unit (OTU) for the purpose of classification and ordination. The bands from 1D-SDS-PAGE or the spots from 2D-peptide mapping were scored as 0 representing absence and 1 representing presence, and employed in the analysis by using NTSYS-pc computer and PAST programs. Cluster analysis and PCA using the protein data from the two different techniques demonstrated that the similarity between $T$. polyceratia and $M$. sativa is more than that to T. foenum-graecum. The present paper accepts the transfer of $T$. polyceratia to Medicago and recommends further studies for $T$. cylindracea.
}

Key words: Peptide mapping, Seed proteins, T. cylindracea, T. polyceratia.

\section{Introduction}

The vindication for the transfer of Trigonella polyceratia to Medicago as " $M$. polyceratia" based on some fine floral structures termed medicagoid characters related to androecia, and those associated with the explosive mode of pollination "the tripping mechanism" (Jurzysta et al., 1988; Small et al., 1987 and 1990; Small \& Fawzy, 1991; Boulos, 1999; Ahmed \& Marzouk, 2002). Also the analyses of nrDNA internal transcribed spacer 
region (nrDNA ITS) and external transcribed spacer region (ETS) data supported the inclusion of medicagoid Trigonella in the genus Medicago (Bena, 2001). Meanwhile, Steele and Wojciechowski (2003) included the medicagoid Trigonella in section Bucerates (where T. polyceratia belonged) with the other species of Medicago based on sequences of the plastid gene matK. However, Small (1989) and Boulos (1999) kept Trigonella cylindracea within genus Trigonella L. On the other hand, Ahmed and Marzouk (2002) recommended the transfer of T. cylindracea to Medicago due to the presence of many anatomical and medicagoid floral characters. Both $T$. polyceratia and $T$. cylindracea exhibited the same triangular outline and anatomical details of the petiole as well as the wax deposits on leaflet hairs. Moreover, they also distinguished by the presence of the thumb and pocket structure, the keel petals are not prominently fused over the top of the staminal column, the conical apex of the staminal column, the standard petal with more than three vein clusters and the same cylindrical pod shape (Ahmed \& Marzouk, 2002). Baum (1968) reported that the existence of the medicagoid corolla and androecium in both Medicago and Trigonella, warrant consideration for inference of their relationship, while the presence of the apparatus designed for tripping is a clear-cut criterion which exists only in Medicago.

The present study is planned to investigate the extent to which seed proteins and peptide mapping may be used to transpose $T$. cylindracea and verify that of $T$. polyceratia to Medicago.

\section{Materials and Methods}

Two seed sources were used for protein extraction: the first from ICARDA (International Center for Agricultural Research in the Dry Areas) at Aleppo, Syria; while the second from NPGS (National Plant Germplasm System) at Washington University, USA (Table1). To achieve the objective of this study two outgroups (reference species): Trigonella foenum-graecum L. and Medicago sativa L., which represent the type species for Trigonella and Medicago respectively, were used. Each species (T. cylindracea or $T$. polyceratia and the two reference species) was represented by a bulked seed sample from individuals of different accessions. Prior to analysis, each seed was selected individually after inspection under the dissecting microscope. Seeds containing obvious defects or those relatively small were rejected. Voucher seed specimens were deposited at the Alexandria University herbarium (ALEX). 
Table 1. Origin, source and accession number of species used in the present study. ICARDA: International Center for Agricultural Research in the Dry Areas, NPGS: National Plant Germplasm System (USA).

\begin{tabular}{|c|c|c|c|}
\hline Species & Origin & source & $\begin{array}{c}\text { Accession } \\
\text { number }\end{array}$ \\
\hline Trigonella foenum-graecum $\mathrm{L}$. & $\begin{array}{l}\text { Syria } \\
\text { Egypt } \\
\text { Morocco } \\
\text { Greece } \\
\text { Turkey }\end{array}$ & $\begin{array}{l}\text { ICARDA } \\
\text { NPGS } \\
\text { NPGS } \\
\text { NPGS } \\
\text { NPGS }\end{array}$ & $\begin{array}{l}\text { IG } 110470 \\
\text { PI } 572539 \\
\text { PI } 613630 \\
\text { PI } 199264 \\
\text { PI } 173136\end{array}$ \\
\hline Trigonella polyceratia (L.) Trautv. & $\begin{array}{l}\text { Turkey } \\
\text { Spain } \\
\text { Morocco }\end{array}$ & $\begin{array}{l}\text { NPGS } \\
\text { NPGS } \\
\text { NPGS }\end{array}$ & $\begin{array}{l}\text { PI } 369154 \\
\text { PI } 244328 \\
\text { PI } 517186\end{array}$ \\
\hline Trigonella cylindracea Desv. & $\begin{array}{l}\text { Syria } \\
\text { Turkey }\end{array}$ & $\begin{array}{l}\text { ICARDA } \\
\text { ICARDA }\end{array}$ & $\begin{array}{l}\text { IG } 16171 \\
\text { IG } 110385\end{array}$ \\
\hline Medicago sativa $\mathrm{L}$. & $\begin{array}{l}\text { Egypt } \\
\text { Greece } \\
\text { Syria } \\
\text { Turkey } \\
\text { Lebanon }\end{array}$ & $\begin{array}{l}\text { ICARDA } \\
\text { ICARDA } \\
\text { ICARDA } \\
\text { ICARDA } \\
\text { ICARDA }\end{array}$ & $\begin{array}{l}\text { IG } 101729 \\
\text { IG } 101060 \\
\text { IG } 101745 \\
\text { IG } 101521 \\
\text { IG } 101605\end{array}$ \\
\hline
\end{tabular}

A typical protocol consists of the separation of proteins by one dimensional polyacrylamide gel electrophoresis (1D-PAGE), enzymatic digestion and the determination of two dimensional peptide fingerprint for each species (2D-peptide fingerprinting) (Hames \& Rickwood, 1990). Here, for 1D-PAGE the discontinuous SDS (Sodium Dodecyle Sulphate) system of Laemmli (1970) was used with some modifications as described by Hames \& Rickwood (1990). One gram of seeds was macerated with sample buffer (2\% SDS, $10 \%$ glycerol, $0.002 \%$ bromophenol blue, $5 \% \beta$ mercaptoethanol), mixed with an equal volume of buffer of $0.5 \mathrm{M}$ Tris- $\mathrm{HCl}$ buffer ( $\mathrm{pH}$ 6.8), submitted to heat treatment for 5 minutes in a boiling water bath, and then cooled to room temperature before centrifuged at $10000 \mathrm{~g}$ for 5 minutes. Finally, the supernatants (containing $45 \mu$ g protein) were loaded 
onto $12.5 \%$ resolving gel using Mini-PROTEAN II cell (Bio-Rad) at $75 \mathrm{~V}$ through the stacking gel followed by $125 \mathrm{~V}$ to the end of the electrophoresis ( 2 hrs). The resultant gel was stained using commasei blue R250 (0.1\% in methanol: glacial acetic acid: water in ratio $3: 1: 6$ ).

For 2D-peptide fingerprinting, the method of Cleveland et al. (1977) was carried out. The bulked proteins of each species were dissolved in $0.05 \mathrm{M}$ Tris- $\mathrm{HCl}(\mathrm{pH} 6.8)$ at concentration $0.25 \%(2.5 \mathrm{mg}$ protein sample $/ \mathrm{ml}$ buffer). A volume of $100 \mu \mathrm{l}$ of each protein solution was mixed with 5,10 , 15 and $20 \mu \mathrm{l}$ of trypsin solution $(20 \mu \mathrm{l} / \mathrm{ml})$ consecutively, placed in a water bath at $37^{\circ} \mathrm{C}$ for 0,1 and 2 hours. Each solution was heated to boiling for 3 minutes to stop enzymatic activity. Then $50 \mu 1$ of sample buffer $(0.0625 \mathrm{M}$ Tris-HCl, $\mathrm{pH}$ 6.8, $10 \%$ glycerol, $0.002 \%$ bromophenol blue) was subjected to $12.5 \%$ first dimension alkaline native-PAGE at $120 \mathrm{~V}$ for 2 hours and stained with commasei blue G250 (Reinheckel et al., 1995). The lanes of the alkaline native-PAGE were separated by SDS-PAGE in the second dimension. The lane of each species sample was cut from the native gel, dipped into a $1 \%$ mercaptoethanol solution for few seconds and placed on a glass plate at usual position of stacking gel. After covering with the second glass plat, $15 \%$ separating gel was added and the rest of the vertical SDSgel was polymerized. Three hours later at $200 \mathrm{~V}$, the gels were stained with commasei blue R250 to visualize the positions of peptide "spot" (GrandierVazeille \& Guerin, 1996).

A standard low protein marker (Sigma) composed of Bovine serum albumin $67 \mathrm{KDa}$, Oval albumin $45 \mathrm{KDa}$, Glyceraldhyde3phosphate 36KDa, Carbonic anhydrase 30KDa, Trypsinogen 24KDa, Trypsin inhibitor 20KDa and $\alpha$-Lactalbumin $14.4 \mathrm{KDa}$ was used according to the method described in Hoefer Protein Electrophoresis Application Guide (1994).

Each species was considered as an operational taxonomic unit (OTU) for the purpose of classification and ordination. The bands (1D-PAGE) or the spots (2D-peptide mapping) were scored as 0 representing absence and 1 representing presence, and employed in the analysis by using NTSYS-pc computer program (Rohlf, 1990) and PAST program (Hammer \& Harper, 2001). For the first program, the agglomerative cluster analysis was conducted using the average Manhattan distance coefficient for mixed data set (Sneath \& Sokal, 1973). The dissimilarity matrix was analyzed by the unweighed pair group method with arithmetic average linkage (UPGMA). For the second program, the average Euclidean coefficient was used, and the similarity matrix was analyzed by single linkage. 
Ordination of the set of OTU's (set of species) was achieved by means of principle component analysis (PCA) and by the construction of the minimum spanning tree as described by Hammer \& Harper (2001).

\section{Results}

The electrophoretic patterns of total seed proteins using 1D-SDS-PAGE for the four studied species are presented in Plate1. A total of 20 peptide bands were recorded and distributed as 8, 10, 9 and 9 bands for Trigonella foenum-graecum, $T$. cylindracea, $T$. polyceratia and Medicago sativa respectively. The molecular weight of bands ranged from 67 to $14.4 \mathrm{KDa}$ in T. foenum-graecum and M. Sativa, from 77.6 to $14.4 \mathrm{KDa}$ in T. cylindracea and from 82.9 to $14.4 \mathrm{KDa}$ in $T$. polyceratia. According to the obtained results, species-specific bands were recorded as a maximum number in $T$. cylindracea, which possessed 5 bands (77.6, 42, 39, 32 and $20 \mathrm{KDa}$ ), and as a minimum number in $T$. polyceratia and $M$. sativa that possessed 2 bands each $(82.9,41 \mathrm{KDa}$ and $45,34 \mathrm{KDa}$ respectively). With respect to $T$. foenum-graecum, 3 species-specific bands were recognized at 43, 22.5 and $18 \mathrm{KDa}$.

In the first step of peptide mapping, the appropriate digestion of proteins in $T$. foenum-graecum and $M$. sativa extracts was achieved by the activity of $20 \mu \mathrm{l}$ trypsin for 2 hours. However, in the cases of $T$. cylindracea and $T$. polyceratia the addition of $5 \mu 1$ enzyme for one hour was sufficient. The first dimension of alkaline native-PAGE is presented in Plate 2, and the peptide mapping (fingerprints) of the four inspected species in Plate $3 \mathrm{a}, \mathrm{b}, \mathrm{c}$ and $d$. The highest proportion of species-specific peptides was recorded in T. polyceratia, where 4 peptides with M.wt. of 33.3, 31.9, 20 and 17.4 KDa are recorded. On the other hand, the lowest proportion of species-specific peptides was found in M. sativa where two bands with M.wt. of 32.7 and $15.2 \mathrm{KDa}$. In 2D peptide mapping of $T$. foenum-graceum and $T$. cylindracea recorded a total of 15 and 12 spots respectively, both are distinguished by moderate proportion of species-specific peptides. The species-specific peptides of $T$. foenum-graecum were detected at M.wt. of $63.9,42.2,23.3,16.3,15$ and $12.6 \mathrm{KDa}$, and those of $T$. cylindracea at M.wt. of 58.5, 43.2, 26.5 and $24.3 \mathrm{KDa}$.

The cluster analysis, by two different programs (NTSYS-pc and PAST) using two types of protein separation techniques (1D-SDS-PAGE and 2D- 
peptide mapping), either separately or pooled together, discriminated the four studied species (Fig. 1). 


$\begin{array}{lllll}4 & 3 & 2 & 1 & \begin{array}{c}\text { Marker } \\ \text { KDa }\end{array}\end{array}$

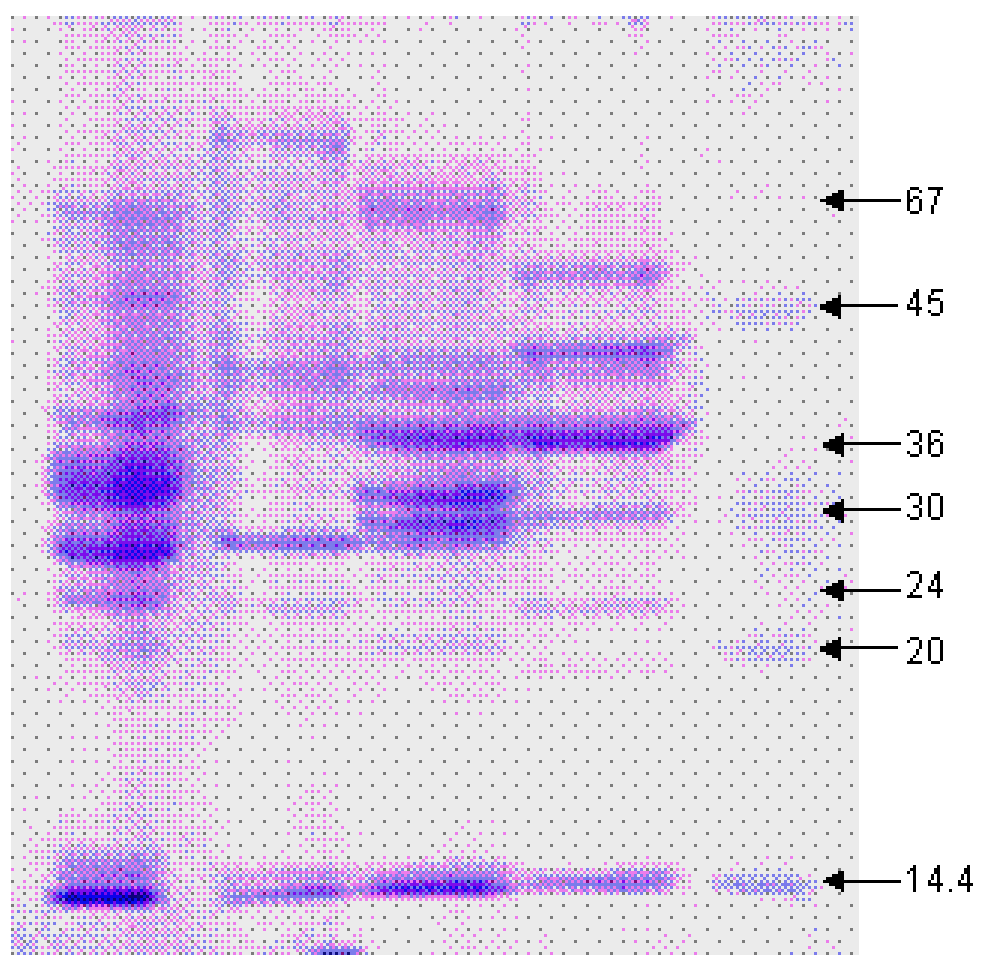

Plate1. The electrophoretic patterns of seed proteins (1D-SDS-PAGE) of the studied species ( $1, T$. foenum-graecum; $2, T$. cylindracea; 3, T. polyceratia and 4, M. sativa). 
Trigonella foenum-graecum is clearly delimited from the other species. This taxonomic tree shows that $T$. polyceratia and $M$. sativa are possibly more related to each other than to $T$. cylindracea, which appeared distinct.

The results of principal component analysis and the minimum spanning trees are shown in relation to the four groups (Fig. 2a and b), which are not highly coincident with those of cluster analysis. Moreover, the principal component analysis for both techniques of protein separation, separately or pooled, indicated that the first two dimensions accounted for approximately $82 \%$ of variance (Table 2 ).

\section{Discussion}

It has been reported by Baum (1968) that the generic demarcation between Medicago and Trigonella, based on traditional taxonomic works relied on fruit attributes is highly debatable by previous authors. Small et al. (1981) indicated that Medicago could be distinguished from Trigonella on the basis of combinations of some floral attributes (as: interlocking wing and keel petals, relatively less apical fusion of the keel petals, relatively well-developed wing petal horn, staminal tubes conical at the apex and with a standard petal having more than three clusters of veins). Moreover, they suggested that Trigonella section Bucerates to be quite distinctive from the remaining Trigonella species. Baum (1968) suggested the detachment of the three sections, Bucerates, Lunatae and Isthmocarpae, which form a part of the 14 Sirjaev's sections of Trigonella, on the account of some floral criteria more specified to Medicago than to Trigonella. The present study verifies the point of view that Trigonella polyceratia, section Bucerates may be treated as Medicago polyceratia. Ingham (1981) by chemotaxonomic investigations and Small et al. (1990) by seed characters supported the transfer of section Bucerates to Medicago. Recently, Ahmed and Marzouk (2002) added more weight for the segregation of $T$. polyceratia from Trigonella based on many anatomical and floral characters (as: petiole anatomy, wax deposits on leaflet hairs and floral characters accompanied by tripping mechanism).

Notwithstanding, Ahmed \& Marzouk (2002) accepted the transposition of T. cylindracea under Medicago, based on shared anatomical and floral characters. Small et al. (1981, 1990) and Boulos (1999) kept T. cylindracea under genus Trigonella. The present investigation does not support the transfer of T. cylindracea to Medicago until further studies are made. 
Seed protein analyses as a support to the transfer ...

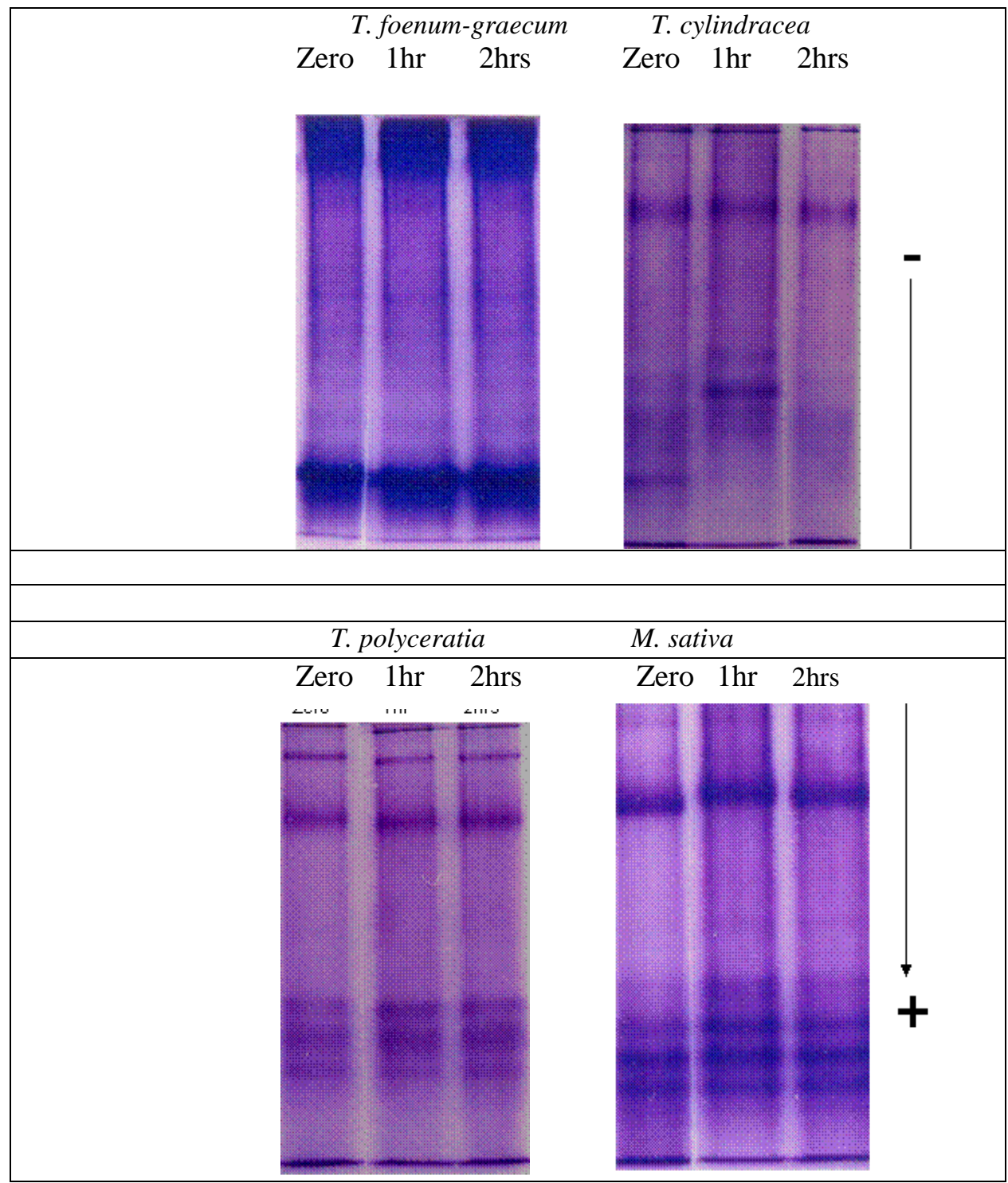

Plate 2. Alkaline native-PAGE of trypsin treated proteins extracted from the studied species. Zero, $1 \mathrm{hr}$ and $2 \mathrm{hrs}$ are samples of trypsin digested proteins at Zero, $1 \mathrm{hr}$ and $2 \mathrm{hrs}$ respectively. 


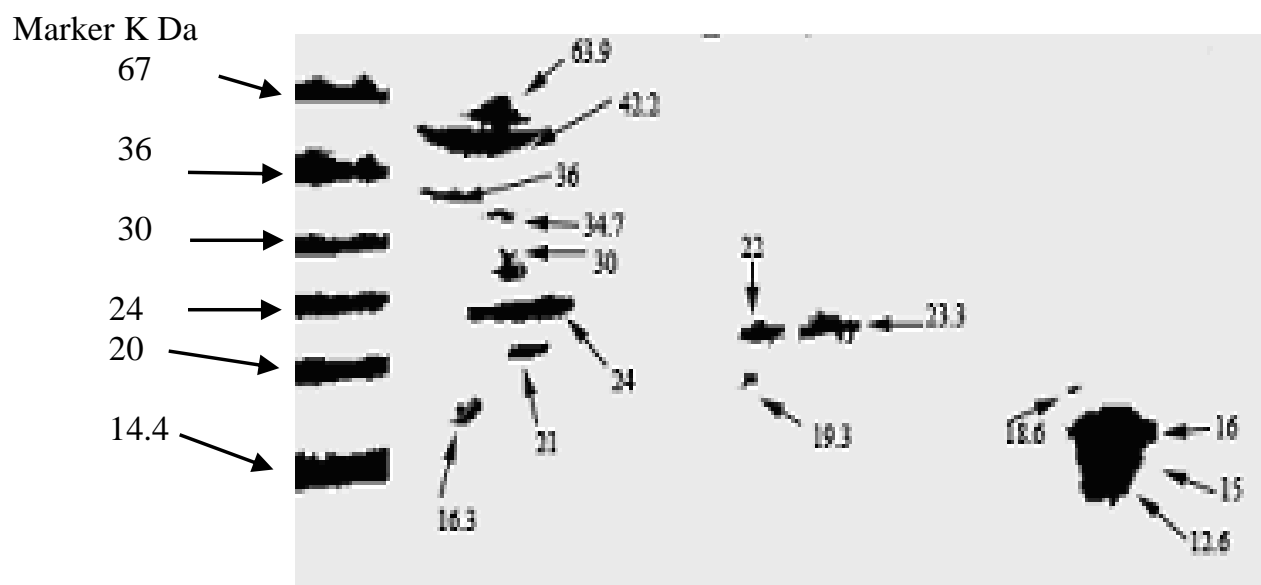

Plate 3a. 2D-Peptide map for alkaline native-PAGE of $20 \mu 1$ trypsin treated proteins extracted and incubated for $2 \mathrm{hrs}$ from $T$.foenum-graceum.

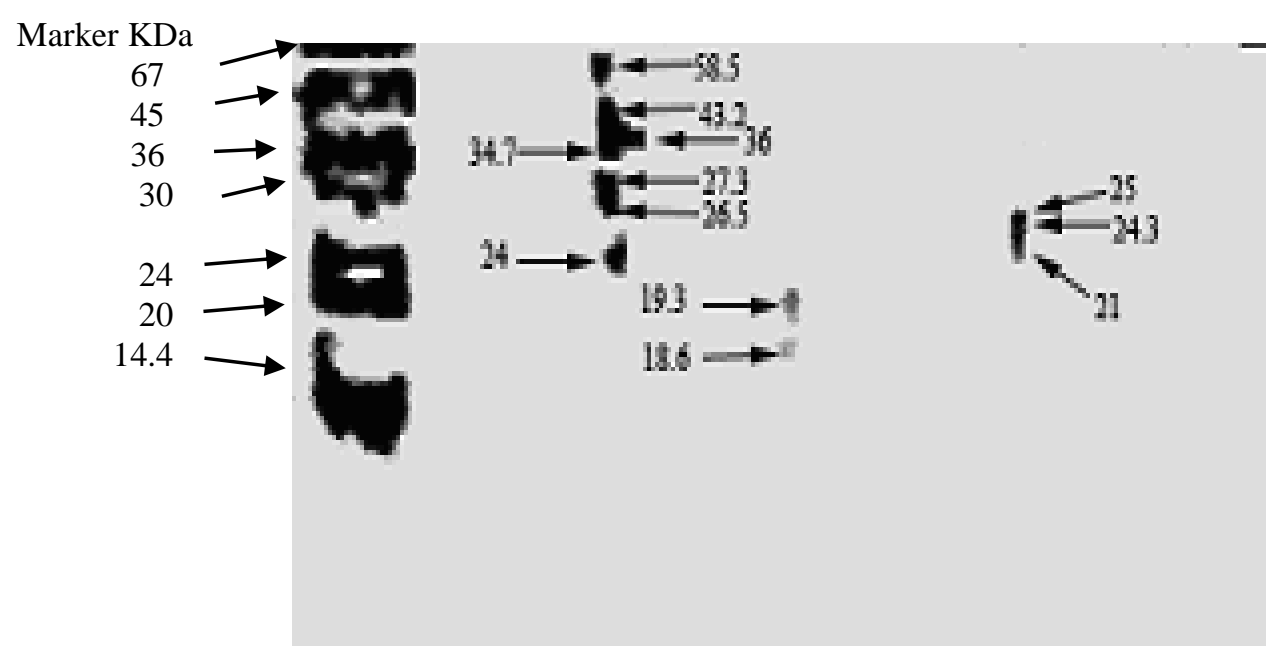

Plate 3b. 2D-Peptide map for alkaline native-PAGE of $5 \mu$ l trypsin treated proteins extracted and incubated for $1 \mathrm{hr}$ from $T$. cylindracea. 
Marker KDa
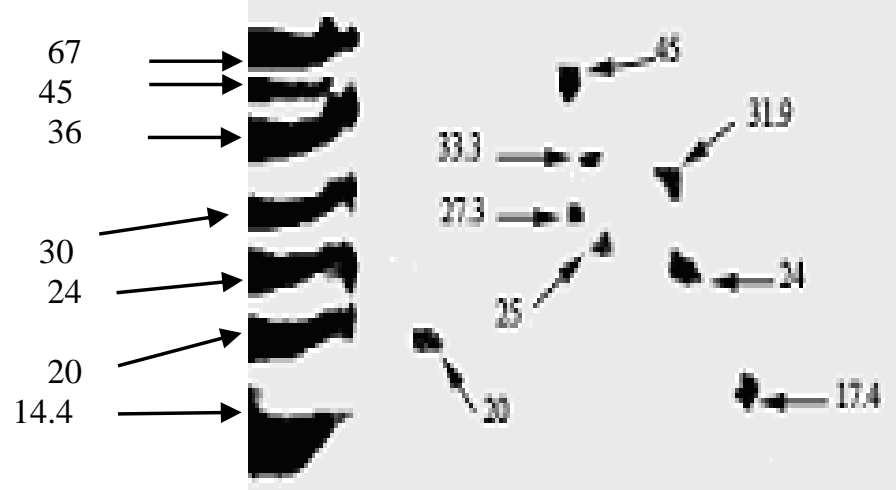

Plate 3c. 2D-Peptide map for alkaline native-PAGE of $5 \mu 1$ trypsin treated proteins extracted and incubated for $2 \mathrm{hrs}$ from $T$. polyceratia.

Marker KDa

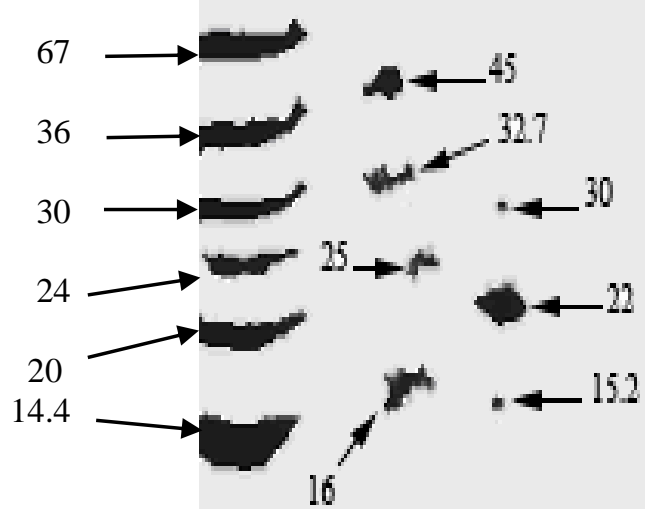

Plate 3d. 2D-Peptide map for alkaline native-PAGE of $20 \mu 1$ trypsin treated proteins extracted and incubated for $2 \mathrm{hrs}$ from $M$. sativa. 


\section{R. I. Marzouk}

Table 2a. Percentage variation accounted for along first two dimensions of PCA using 1D-SDS-PAGE

\begin{tabular}{lcc} 
& Value & \%Variance \\
\hline \hline Eigenvalue 1 & 2 & 42.8571 \\
Eigenvalue 2 & 1.8047 & 38.673
\end{tabular}

Table 2b. Percentage variation accounted for along first two dimensions of PCA using 2D-peptide mapping

$$
\text { Value } \quad \% \text { Variance }
$$

\begin{tabular}{lll}
\hline \hline & & \\
Eigenvalue 1 & 3.67555 & 46.922
\end{tabular}

$\begin{array}{lll}\text { Eigenvalue } 2 & 2.7401 & 34.981\end{array}$

Table 2c. Percentage variation accounted for along first two dimensions of PCA using both 1D-SDS-PAGE and 2D-peptide mapping

$$
\text { Value } \quad \text { Variance }
$$

\begin{tabular}{lll}
\hline \hline & & \\
Eigenvalue 1 & 5.67799 & 46.9903
\end{tabular}

$\begin{array}{lll}\text { Eigenvalue } 2 & 3.7933 & 31.392\end{array}$



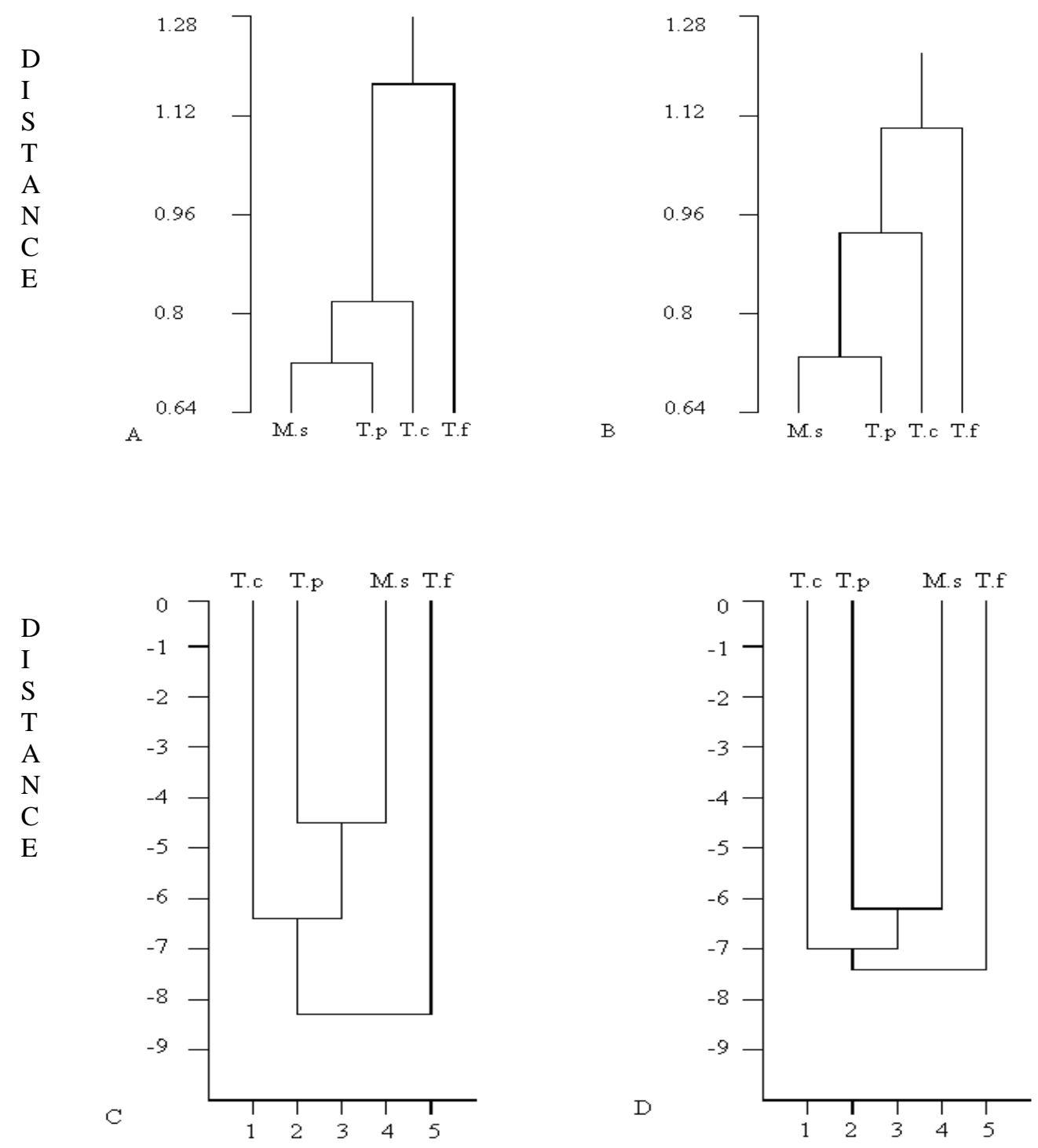

Fig. 1. Dengrogram from 1D-SDS-PAGE (A) and (C) using both NTSYS-pc program and PAST program, respectively. Dendrogram either from 2D-peptide mapping or from both 1D-SDS-PAGE and 2D-peptide mapping (B) and (D) using NTSYS-pc program and by PAST program, respectively; T.f, T. foenum-graceum; T.c, $T$. cylindracea; T.p, T. polyceratia; M.s, M. sativa. 


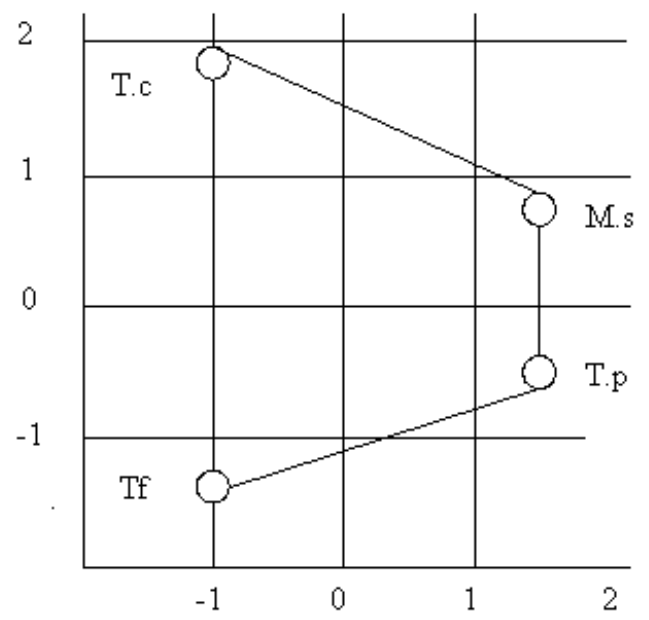

Fig. 2a. Two dimensional plot of the first two components of the four studied species using 1D-SDS-PAGE; T.f., T. foenum-graceum; T.c., T. cylindracea; T.p. T. polyceratia and M.s., M. sativa.

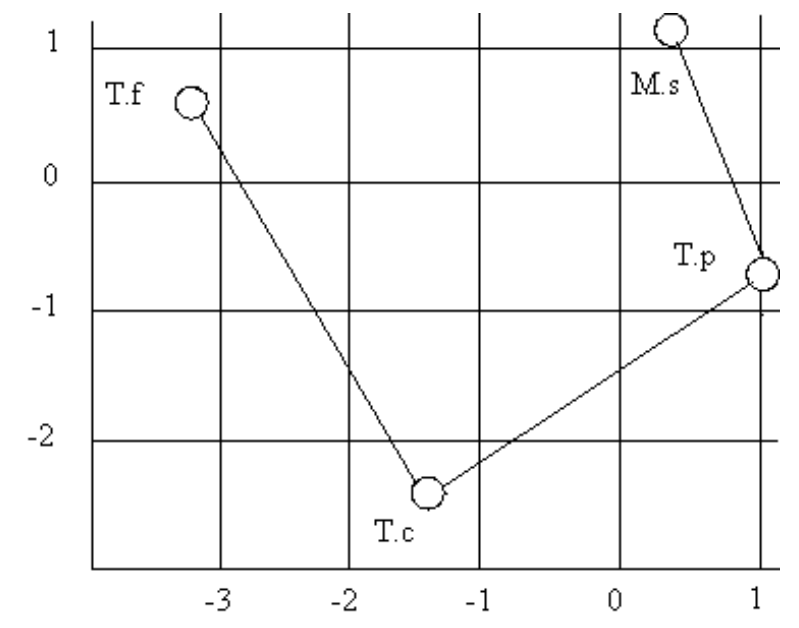

Fig. 2b. Two dimensional plot of the first two components of the four studied species using either 2D-peptide mapping or both 1D-SDS-PAGE and 2D-peptide mapping; T.f., $T$. foenum-graceum; T.c., T. cylindracea; T.p. T. polyceratia and M.s., M. sativa.

In the current study, cluster analysis and PCA using protein data obtained from both 1D-SDS-PAGE and 2D-peptide mapping or from the data of both two types demonstrated that the similarity between both $T$. 
cylindracea and $T$. polyceratia on one hand and $M$. sativa on the other is more than that to T. foenum-graecum. This notable demarcation in the case of 1D-SDS-PAGE more than that of 2D-peptide mapping may be due to the more specificity of the later technique and the generalized form of proteins in the former one.

The results of 1D-SDS-PAGE signify the following points:

1. Both Trigonella and Medicago share three common bands at 67, 31 and $14.4 \mathrm{KDa}$, which is congruent with their grouping in subtribe Trigonellinae (Small, 1987).

2. Trigonella cylindracea, T. polyceratia and Medicago sativa share one band at $27.5 \mathrm{KDa}$, while $T$. foenum-graecum is distinguished by three specific bands at 43, 22.5 and $18 \mathrm{KDa}$.

3. There are two bands common to $T$. polyceratia and $M$. sativa at 37 and $23 \mathrm{KDa}$, while, a single band is shared between T. cylindracea and $M$. sativa at 20KDa.

From the acquired results, it can be deduced that peptide mapping for each of the studied species is unique and can be used for the discrimination of each species. Wilson et al. (1991) concluded that peptide mapping as a technique for systematic research appears most useful at the intergeneric level. It can be also noticed that proteins of $T$. foenum-graecum and $M$. sativa are less affected by trypsin $(20 \mu \mathrm{l}$ for 2hours) than the two other species $(5 \mu 1$ for 1 hour), which reflect the presence of highly resistant proteins in the two former species contrary to the highly susceptible ones in the two later species.

The 2D-peptide mapping of the four examined species, signify the following points:

1. There are no common peptide bands among the four species. On the other hand a peptide of $25 \mathrm{KDa}$ is common to $T$. cylindracea, $T$. polyceratia and $M$. sativa together.

2. The presence of one $27.3 \mathrm{KDa}$ band in T. polyceratia and M. sativa and one $45 \mathrm{KDa}$ band in T. cylindracea and M. sativa.

3. Trigonella foenum-graecum is characterized by the widest range of peptide bands from $63.9 \mathrm{KDa}$ to $12.6 \mathrm{KDa}$, while the narrowest range, from $45 \mathrm{KDa}$ to $17.4 \mathrm{KDa}$ distinguishes $T$. polyceratia.

4. Trigonella foenum-graecum and T. cylindracea share five peptides of molecular weights: 36, 34.7, 21, 19.3 and 18.6 KDa and. In spite 
of these similarities, $T$. cylindracea segregated from $T$. foenumgraecum in the cluster analysis and PCA, that may be due to: (a) the relatively high number of peptide bands in these two species (12 and 15 bands respectively) or (b) the presence of 3 shared peptides between T. foenum-graecum and M. sativa at 30, 22 and $16 \mathrm{KDa}$.

The present paper suggested the transposition of $T$. polyceratia to Medicago, and for T. cylindracea recommended more studies for clear-cut decision. Given the good congruence between morphological characteristics and both 1D-SDS-PAGE and peptide mapping (fingerprint) which maximize the usage of these characters in solving taxonomic problems especially those closely related.

\section{Acknowledgements}

The author is deeply grateful to Prof. Dr. Laila El-Sadek, Professor of cytology and genetics, Alexandria University for her valuable guidance and support.

\section{References}

Ahmed, M.F. and Marzouk, R.I. 2002. A numerical study on the genus Trigonella L. (Leguminosae) in Egypt. Proc. $2^{\text {nd }}$ Int.Conf.Biol.Sci. (ICBS) Fac.Sci., Tanta University. 27-28 April, 2: 189-222.

Baum, B.R. 1968. A clarification of the generic limits of Trigonella and Medicago. Can. J. Bot. 46:741-749.

Bena, G. 2001. Molecular phylogeny supports the morphologically based taxonomic transfer of the "medicagoid" Trigonella species to the genus Medicago L. Plant Systematics and Evolution. 229: 217-236.

Boulos, L. 1999. Flora of Egypt. Volume 1 (Azollaceae to Oxalidaceae). Al-Hadara Publishing, Cairo, Egypt.

Cleveland, D.W., Ficher, S.G., Kirchner, M.W. and Laemmli, U.K. 1977. Peptide mapping by limited proteolysis in sodium dodecyle sulphate and analysis by gel electrophoresis. J. Biol. Chem. 252: 1102-1106.

Grandier-Vazeille, X. and Guerin, M. 1996. Separation by blue native and colorless native polyacrylamide gel electrophoresis of the oxidative phosphorylation complexes of yeast mitochondria solubilized by different detergents. Anal. Biochem. 242: 248-254. 
Hammer, V. and Harper, D.A.T. 2001. PAST, Version 0.45. http://www.uio.no/ ohammer/past.

Hames, B.D. and Richwood, D. 1990. In: Gel Electrophoresis of Proteins. A Practical approach. TRL Publishing Co. London, England.

Hoefer, .1994. Protein Electrophoresis. Application Guide.. Hoefer Scientific Instruments. USA

Ingham, J.L. 1981. Phytoalexin induction and its taxonomic significance in the Leguminosae (subfamily Papilionoideae). In: Advances in Legume Systematics. Part 2. 599-626. Eds. Polhill, R.M. and Raven, P.H. Royal Botanic Gardens, Kew.

Jurzysta, M., Small, E. and Nozzolillo, C. 1988. Hemolysis, a synapomorphic discriminator of an expanded genus Medicago (Leguminosae). Taxon 37: 354-363.

Laemmli, U.K. 1970. Cleavage of structural proteins during the assembly of the head of bacteriophage T4. Nature. 277:680-685.

Lesins, K.A. and Lesins, I. 1979. Genus Medicago (Leguminosae). A taxogenetic study. W.Junk, The Hague.

Reinheckel, T., Wiswedel, I., Noack, H. and Augustin, W. 1995. Electrophoretic evidence for the impairment of complexes of the respiratory chain during iron ascorbate induced peroxidation in isolated rat liver mitochondria. Biochem. Biophys. Acta. 1239: 45-50.

Rohlf, F.J. 1990. NTSYS-pc Numerical Taxonomy and Multivariate Analysis System. Version 1.50. Applied Biostatistics Inc. New York.

Small, E. 1987. Generic changes in Trifolieae subtribe Trigonellinae. In: Advances in Legume Systematics. Part 3. 169-181. Ed. Stirton, C.H. Royal Botanic Garden, Kew. -- 1989. Polythetic generic separation in tribe Trifolieae subtribe Trigonellinae (Leguminosae). Can. J. Bot. 67: 1480-1492.

--------- and Fawzy, M. 1991. A clarification of the genus Medicago polyceratia Medicago orthoceras complex. Can. J. Bot. 69: 19071912.

--, Crompton, C.W. and Brookes, B. 1981. The taxonomic value of floral characters in tribe Trigonelleae (Leguminosae) with special reference to Medicago. Can. J. Bot. 59: 1578-1598.

-, Lassen, P. and Brookes, B.S. 1987. An expanded circumscription of Medicago (Leguminosae, Trifolieae) based on explosive flower tripping. Willdenowia. 16: 415-437. 
Brookes, B.S. and Lassen, P. 1990. Circumscription of the genus Medicago (Leguminosae) by seed characters. Can. J. Bot. 68: 613629.

Sneath, P.H. and Sokal, R.P. 1973. Numerical Taxonomy. $2^{\text {nd }}$ ed. W.H. Freeman, San Francisco.

Steele, K.P. and Wociechowski, M.F. 2003. Phylogenetic analyses of tribes Trifolieae and Vicieae, based on sequences of the plastid gene, matK (Papilionoideae: Leguminosae). In: Advances in Legume Systematics. Part 10, Higher Leevel Systematics. 355-370. Eds. Klitgaard, B.B. and Bruneau, A. Royal Botanic Gardens, Kew.

Wilson, R.R., Siebenaller, J.F. and Davis, B.J. 1991. Phylogenetic analysis of species of three subgenera of coryphaenoides (Teleostei:Macrouridae) by Peptide mapping of homologs of Idh-a4. Bioch. Syst. Ecol.19: 277-287. 